\title{
Fatty Acid Composition of Lipoprotein Lipids in Hepatobiliary Diseases ${ }^{1}$ )
}

\author{
Maria Isabel Arranz', Miguel Angel Lasunción ${ }^{2}$, José Perales ${ }^{3}$, Emilio Herrera ${ }^{2}$, Isabel Lorenzo ${ }^{1}$, \\ Cristina Cárcamo', Luis Concostrina ${ }^{1}$, Juan Villar ${ }^{1}$ and Rafael Gasalla ${ }^{1}$ \\ 1 Servicio de Bioquímica Clínica \\ 2 Servicio de Bioquímica de Investigación \\ 3 Servicio de Medicina Interna \\ Hospital "Ramón y Cajal", Madrid, Spain
}

Summary: Liver damage and alterations in the exocrine function of the gland lead to a profound alteration of the plasma lipoprotein profile. To determine whether hepatic disease results in changes in the lipoprotein fatty acid composition, i. e. to determine whether liver function influences the homeostasis of complex lipids in plasma, we studied the fatty acid profile of lipids from VLDL, LDL and HDL, as well as from total plasma, in thirty-one patients of both sexes with hepatobiliary pathology (compensated liver cirrhosis, uncompensated liver cirrhosis, primary biliary cirrhosis, other intrahepatic cholestasis, and acute viral hepatitis). We also studied a group of healthy adults as controls. We present the lipoprotein profile and the fatty acid composition (myristic C14, palmitic C16, palmitoleic $\mathrm{C} 16: 1$, stearic $\mathrm{C} 18$, oleic $\mathrm{C} 18: 1$, linoleic $\mathrm{C} 18: 2$, eicosatrienoic $\mathrm{C} 20: 3 \omega 6$ and arachidonic $\mathrm{C} 20: 4$ ) of lipoprotein and total plasma triacylglycerols, cholesteryl esters and phospholipids. The main observation of this study is that, despite the profound changes in the lipoprotein profile and the lower abundance of polyunsaturated fatty acids in complex lipids, the composition of all triagylglycerols, cholesteryl esters and phospholipids is very similar for the corresponding lipoproteins of patients with hepatobiliary disease and of control subjects. This indicates that in the controls as in the studied patients, the exchange of lipids between plasmatic lipoproteins is very rapid and demonstrates the possible importance of the extrahepatic synthesis of cholesteryl ester transfer protein.

\section{Introduction}

The liver has a central role in the synthesis of polyunsaturated fatty acids and in lipoprotein metabolism. It is site of synthesis of the greater part of arachidonic acid, cholesterol, triacylglycerols, phospholipids and apoproteins that circulate in plasma as lipoproteins. Liver also produces and secretes lecithin : cholesterol acyltransferase $^{2}$ ), a plasmatic enzyme that esterifies the cholesterol collected from the cells by HDL (1), and cholesteryl ester transfer protein which allows the exchange of neutral lipids between the different classes of lipoproteins in plasma (2). Liver damage and alterations in the exocrine function of the gland lead to a profound alteration of the plasma lipid profile, modifying the lipoprotein content of total and esterified cholesterol, triacylglycerols, phospholipids (3) and apolipoproteins (4), as well as the activities of lecithin : cholesterol acyltransferase (5), cholesteryl ester transfer protein $(6 ; 7)$ and hepatic lipase

\footnotetext{
1) This work was supported in part by the Fondo de Investigaciones Sanitarias (94/0484), Spain.

2) Enzymes

Alkaline phosphatase (EC 3.1.3.1), Aspartate aminotransferase (EC 2.6.1.1), $\gamma$-Glutamyl transferase (EC 2.3.2.2), Lecithin : cholesterol acyltransferase (EC 2.3.1.43).
}

(8). Liver damage also influences the transformations of polyunsaturated fatty acids (9).

The fatty acid composition of plasma lipids is a reflection of the type of fatty acids in the diet, and of the synthesis and transformation of fatty acids in the organism. The different classes of complex lipids - triacylglycerols, cholesteryl esters and phospholipids - have different compositions of fatty acids. The fatty acid composition of these complex lipids in the different lipoproteins has been studied in detail in healthy subjects, and shown to be similar in VLDL, LDL and HDL (1011), thus confirming the rapid exchange of these lipids between these lipoproteins, mediated by the transfer proteins. In contrast, in animal species that lack cholesteryl ester transfer protein, such as the rat and the pig, the fatty acid profile of cholesteryl esters in the distinct lipoproteins is different $(12-13)$.

In patients with liver diseases, especially those with cirrhosis, the fatty acid composition of triacyclglycerols, cholesteryl esters and phospholipids from total plasma is markedly different from that of healthy subjects $(9$, 14-15), but the fatty acid profiles of these lipid fractions from the different lipoproteins have not been studied. It is therefore necessary to determine the distri- 
bution of lipid species among the different lipoproteins in hepatic disease. A non-homogeneous distribution would reflect an alteration in plasmatic lipoprotein metabolism.

All these data underline the influence of the functional state of the liver on the availability of energy-yielding substrates, and they indicate possible effects on the activity of cholesteryl ester transfer protein.

In the present work, to determine the influence of the liver function on the homeostasis of complex lipids in plasma, we have studied the lipoprotein profile and the fatty acid composition of lipids from VLDL, LDL and HDL, as well as from total plasma, in several groups of patients with hepatobiliary pathology.

\section{Materials and Methods}

\section{Subjects}

Thirty-six patients of both sexes, between the ages of 23 and 72 years were studied. Twelve suffered from liver cirrhosis, in the majority of cases of ethylic origin, that was uncompensated in 7 and compensated in the rest. Fourteen had primary biliary cirrhosis, 8 in stages I and II and the remaining in III. The evolution of the disease in the patients was from 1 to 10 years. Five patients presented other intrahepatic cholestasis distinct from primary biliary cirrhosis, 2 of sclerotic cholangitis and 3 of a pharmacological origin. In the other intrahepatic cholestasis group, the evolution of the disease was 1 to 10 months. Five patients presented acute viral hepatitis, and were studied within 15 days of diagnosis. The age and sex distribution of the 6 healthy adults comprising the control group were similar to those of the patients. None was receiving medication or diet that could alter the lipid metabolism or the fatty acids. All samples for analysis were taken after fasting for 12 hours.

\section{Isolation of lipoproteins and lipid analysis}

Biood was withdrawn from patients and controls after a 12 hour period of fasting. Blood was collected over EDTA $\cdot \mathrm{Na}_{2}(1 \mathrm{~g} / \mathrm{l})$ and rapidly centrifuged at $4{ }^{\circ} \mathrm{C}$ for plasma separation. Lipoproteins ${ }^{3}$ ) were isolated from a $10 \mathrm{ml}$ plasma aliquot by sequential ultracentrifugation with a Beckman 50 Ti rotor in a Beckman L5-50 ultracentrifuge (Beckman Instruments, Palo Alto, CA), as described (18), at the following density ranges: very low-density lipoproteins (VLDL), d < $1.006 \mathrm{~kg} / \mathrm{l}$; low-density lipoproteins (LDL), d 1.006 to $1.063 \mathrm{~kg} / \mathrm{l}$; high-density lipoproteins (HDL), d 1.063 to 1.21 $\mathrm{kg} /$. All salt solutions for density adjustment contained $1 \mathrm{mmol} / \mathrm{l}$ EDTA $\cdot \mathrm{Na}_{2}$. The lipoprotein-containing supernatants were used for lipid analysis and determination of fatty acid profile without any further manipulation. Total cholesterol, free cholesterol, triacylglycerols and phosphatidylcholine were measured enzymatically in an autoanalyser Technicon RA-1000 (Technicon Ltd., Dublin, Ireland). Esterified cholesterol was calculated as the difference between total and free cholesterol. Glycerol was measured in deproteinized plasma (19) and this value was subtracted from those of triacyclglycerols in total plasma and in lipoprotein fractions. Total bilirubin, and albumin concentrations, as well as aspartate aminotransferase ${ }^{2}$ ), $\gamma$-glutamyl transferase ${ }^{2}$ ), and alkaline phosphatase ${ }^{2}$ ) activities were measured in serum in an Hitachi 747 autoanalyser.

\section{Fatty acid profile analysis}

Lipids were extracted from lipoprotein fractions and total plasma with chloroform/methanol $(2+1$, by vol.), (16). After extraction,

$\left.{ }^{3}\right)$ Lipoproteins VLDL, very low-density lipoproteins, $(\mathrm{d}<0.006$ $\mathrm{kg} / \mathrm{l})$; LDL, low-density lipoproteins, $(\mathrm{d}=1.006-1.063 \mathrm{~kg} / \mathrm{l})$; $\mathrm{HDL}$, high-density lipoproteins, $(\mathrm{d}=1.063-1.21 \mathrm{~kg} / \mathrm{l})$. the phospholipids, triacyclglycerols and cholesterol ester fractions were separated by thin layer chromatography, and their constituent fatty acids were methylated before analysis with $4 \mathrm{ml}$ of sulphuric acid/methanol $\left(1+2\right.$, by vol.) for $3 \mathrm{~h}$ at $65^{\circ} \mathrm{C}$. Separation and quantitation of fatty acids was accomplished at $180^{\circ} \mathrm{C}$ in a Perkin Elmer 3920 B gas liquid chromatograph (Perkin Elmer Corp., Norwalk, CT), equipped with a $2 \mathrm{~m} \times 2 \mathrm{~mm}$ I.D. glass column filled with $5 \%$ of diethylene glycol succinate on gas chrom Q 100-120 mesh. Quantitation was based on comparison of the relative responses of the fatty acid methyl esters in the sample with the responses of pure standards (Sigma, Chemical Co., Sigma-Aldrich Quimica S. A.).

\section{Statistical analysis}

Fatty acid methyl esters (percentages) from the different lipoproteins and plasma lipid fractions were determined for each disease and compared with those of the control group by the Newman Keuls Hartley test.

\section{Results}

Table 1 presents the general biochemical profile of the different groups of patients, and includes the results of the serum monitoring of aspartate aminotransferase, $\gamma$ glutamyl transferase, and alkaline phosphatase activities, and total bilirubin and albumin concentrations. In the profiles of the two cirrhotic patient subgroups, the hypoalbuminaemia and increase of bilirubin in the metabolically uncompensated is notable, compared with the values for the compensated clinical state. The other biochemical quantities serving as indicators of the liver function were altered in the two subgroups, but with a greater statistical significance in the more seriously ill patients.

In the group of patients with intrahepatic cholestasis, there was a significant increase in the total bilirubin concentration, except in those included in subgroup primary biliary cirrhosis with primary, as yet incipient biliary cirrhois (stages I and II). The greatest alteration in the liver enzyme activities and increase of total bilirubin were found in the patients with primary biliary cirrhosis in stage III, compared with the other groups. The profile of those suffering from other intrahepatic cholestasis was the least altered in comparison with the controls.

The lipoprotein profiles of all the groups are summarized in table 2; those of the patients with primary biliary cirrhosis I and II are most similar to those of the controls. In the patients with liver cirrhosis (uncompensated liver cirrhosis and compensated liver cirrhosis), the most remarkable observation was the low levels of triacyclglycerols with normal levels of cholesterol in total plasma. In these cases, the lipoprotein profile showed a reduced number of VLDL particles, as indicated by the diminished content of both triacyclglycerols and cholesterol in this fraction, and the presence of LDL enriched with respect to triacylglycerols. In addition, HDL-cholesterol was decreased in the uncompensated liver cirrhosis group. In patients with acute viral hepatitis, and 
Tab. 1 Hepatic function tests of patients with hepatobiliary dis- Serum samples were used for the evaluation of hepatic properties eases and controls. by routine analyses.

\begin{tabular}{|c|c|c|c|c|c|c|c|}
\hline & $\begin{array}{l}\text { Uncompen- } \\
\text { sated liver } \\
\text { cirrhosis } \\
(n=7)\end{array}$ & $\begin{array}{l}\text { Compen- } \\
\text { sated liver } \\
\text { cirrhosis } \\
(n=5)\end{array}$ & $\begin{array}{l}\text { Primary } \\
\text { biliary } \\
\text { cirrhosis in } \\
\text { stages I, II } \\
(n=8)\end{array}$ & $\begin{array}{l}\text { Primary } \\
\text { biliary } \\
\text { cirrhosis in } \\
\text { stage III } \\
(n=6)\end{array}$ & $\begin{array}{l}\text { Acute } \\
\text { viral } \\
\text { hepatitis } \\
(n=5)\end{array}$ & $\begin{array}{l}\text { Other } \\
\text { intrahepatic } \\
\text { cholestasis } \\
(n=5)\end{array}$ & $\begin{array}{l}\text { Controls } \\
(n=6)\end{array}$ \\
\hline $\begin{array}{l}\text { Aspartate amino- } \\
\text { transferase }^{\mathrm{a}, \mathrm{b}}(\mathrm{U} / \mathrm{l})\end{array}$ & $97 \pm 74^{c}$ & $73 \pm 49^{c}$ & $118 \pm 29^{e}$ & $187 \pm 139^{c}$ & $931 \pm 637^{c}$ & $56 \pm 24^{c}$ & $18 \pm 8$ \\
\hline $\begin{array}{l}\gamma \text {-Glutamyl } \\
\text { transferase }{ }^{\mathrm{a}, \mathrm{b}}(\mathrm{U} / \mathrm{l})\end{array}$ & $132 \pm 78^{d}$ & $119 \pm 85$ & $272 \pm 155^{d}$ & $372 \pm 284^{d}$ & $152 \pm 84^{d}$ & $64 \pm 27$ & $23 \pm 18$ \\
\hline $\begin{array}{l}\text { Alkaline phos- } \\
\text { phatase }^{\mathrm{a}, \mathrm{b}}(\mathrm{U} / \mathrm{l})\end{array}$ & $329 \pm 125^{c}$ & $\begin{array}{c}354 \pm 298 \\
:\end{array}$ & $875 \pm 589^{c}$ & $2093 \pm 1691^{c}$ & $427 \pm 168^{c}$ & $316 \pm 223$ & $160 \pm 87$ \\
\hline $\begin{array}{l}\text { Bilirubin }{ }^{a, b} \\
(\mu \mathrm{mol} / \mathrm{l})\end{array}$ & $97 \pm 22^{e}$ & $32 \pm 21$ & $43 \pm 39$ & $132 \pm 99^{c}$ & $270 \pm 157^{d}$ & $108 \pm 82^{c}$ & $14 \pm 9$ \\
\hline Albumin $^{\mathrm{a}, \mathrm{b}}(\mathrm{g} / \mathrm{l})$ & $26 \pm 3^{d}$ & $38 \pm 2$ & - & - & - & - & $41 \pm 6$ \\
\hline
\end{tabular}

a Means \pm S. D.

b Significant differences between groups and control at ${ }^{c} p<0.05$,

${ }^{d} \mathrm{p}<0.01,{ }^{\mathrm{e}} \mathrm{p}<0.001$

Tab. 2 Serum lipoprotein lipids of patients with hepatobiliary diseases and controls.
Plasma samples were subjected to sequential ultracentrifugation for lipoprotein isolation, and the lipid composition was evaluated by enzymatic analyses.

\begin{tabular}{|c|c|c|c|c|c|c|c|}
\hline & $\begin{array}{l}\text { Uncompen- } \\
\text { sated liver } \\
\text { cirrhosis } \\
(n=7)\end{array}$ & $\begin{array}{l}\text { Compen- } \\
\text { sated liver } \\
\text { cirrhosis } \\
(n=5)\end{array}$ & $\begin{array}{l}\text { Primary } \\
\text { biliary } \\
\text { cirrhosis in } \\
\text { stages I, II } \\
(\mathrm{n}=8)\end{array}$ & $\begin{array}{l}\text { Primary } \\
\text { biliary } \\
\text { cirrhosis in } \\
\text { stage III } \\
(n=6)\end{array}$ & $\begin{array}{l}\text { Acute } \\
\text { viral } \\
\text { hepatitis } \\
(n=5)\end{array}$ & $\begin{array}{l}\text { Other } \\
\text { intrahepatic } \\
\text { cholestasis } \\
(n=5)\end{array}$ & $\begin{array}{l}\text { Controls } \\
(n=6)\end{array}$ \\
\hline $\begin{array}{l}\text { Total cholesterol }{ }^{\mathrm{a} . \mathrm{b}} \\
(\mathrm{mmol} / \mathrm{l})\end{array}$ & $4.40 \pm 1.45$ & $4.06 \pm 1.40$ & $5.20 \pm 0.98$ & $7.84 \pm 3.48^{c}$ & $5.30 \pm 1.80$ & $4.81 \pm 0.50$ & $4.89 \pm 1.18$ \\
\hline $\begin{array}{l}\text { Free cholesterol }{ }^{\mathrm{a} \cdot \mathrm{b}} \\
(\mathrm{mmol} / \mathrm{l})\end{array}$ & $1.64 \pm 0.80$ & $1.36 \pm 0.49$ & $1.54 \pm 0.32$ & $3.56 \pm 3.22$ & $2.28 \pm 0.65^{\mathrm{c}}$ & $1.72 \pm 0.88$ & $1.36 \pm 0.41$ \\
\hline $\begin{array}{l}\text { Esterified choles- } \\
\text { terol }^{\mathrm{a}, \mathrm{b}}(\mathrm{mmol} / \mathrm{l})\end{array}$ & $2.45 \pm 0.78$ & $2.72 \pm 0.50$ & $3.66 \pm 1.03$ & $4.25 \pm 1.36$ & $2.83 \pm 1.86$ & $3.10 \pm 1.78$ & $3.46 \pm 0.93$ \\
\hline $\begin{array}{l}\text { Fraction of esteri- } \\
\text { fied cholesterol }{ }^{\mathrm{a}, \mathrm{b}}(\%)\end{array}$ & $64 \pm 9$ & $67 \pm 5$ & $71 \pm 7$ & $63 \pm 25$ & $52 \pm 19^{c}$ & $44 \pm 16$ & $72 \pm 4$ \\
\hline $\begin{array}{l}\text { Triacylglycerols } \mathrm{s}^{\mathrm{a}, \mathrm{b}} \\
(\mathrm{mmol} / \mathrm{l})\end{array}$ & $0.80 \pm 0.30^{d}$ & $0.65 \pm 0.11^{d}$ & $0.95 \pm 0.29$ & $1.50 \pm 0.82$ & $3.06 \pm 0.87^{e}$ & $2.58 \pm 1.53$ & $1.15 \pm 0.23$ \\
\hline $\begin{array}{l}\text { LDL-cholesterol }{ }^{\mathrm{a}, \mathrm{b}} \\
(\mathrm{mmol} / \mathrm{l})\end{array}$ & $3.40 \pm 1.62$ & $2.66 \pm 1.09$ & $3.50 \pm 0.72$ & $6.00 \pm 3.43$ & $3.94 \pm 1.80$ & $3.56 \pm 1.64$ & $3.37 \pm 0.70$ \\
\hline $\begin{array}{l}\text { LDL-triacylglyc- } \\
\text { erols }^{\mathrm{a}, \mathrm{b}}(\mathrm{mmol} / \mathrm{l})\end{array}$ & $0.47 \pm 0.22^{d}$ & $0.32 \pm 0.09^{d}$ & $0.32 \pm 0.15$ & $0.58 \pm 0.48$ & $1.76 \pm 0.64^{e}$ & $0.82 \pm 0.53$ & $0.15 \pm 0.03$ \\
\hline $\begin{array}{l}\text { HDL-choles- } \\
\text { terol }\end{array}$ & $0.67 \pm 0.86^{d}$ & $1.14 \pm 0.49$ & $1.37 \pm 0.57$ & $1.55 \pm 0.49$ & $0.72 \pm 0.28^{c}$ & $0.49 \pm 0.18^{d}$ & $1.09 \pm 0.21$ \\
\hline $\begin{array}{l}\text { HDL-triacylglyc- } \\
\text { erols }^{\mathrm{a}, \mathrm{b}}(\mathrm{mmol} / \mathrm{l})\end{array}$ & $0.09 \pm 0.06$ & $0.13 \pm 0.05$ & $0.14 \pm 0.05$ & $0.25 \pm 0.10^{c}$ & $0.17 \pm 0.06$ & $0.11 \pm 0.05$ & $0.11 \pm 0.02$ \\
\hline $\begin{array}{l}\text { VLDL-cholestes- } \\
\text { terol }{ }^{\mathrm{a}, \mathrm{b}}(\mathrm{mmol} / \mathrm{l})\end{array}$ & $0.08 \pm 0.05^{e}$ & $0.05 \pm 0.03^{e}$ & $0.16 \pm 0.13$ & $0.30 \pm 0.23$ & $0.49 \pm 0.01^{d}$ & $0.65 \pm 0.72$ & $0.23 \pm 0.03$ \\
\hline $\begin{array}{l}\text { VLDL-triacylglyc- } \\
\text { erols }^{\mathrm{a}, \mathrm{b}}(\mathrm{mmol} / \mathrm{l})\end{array}$ & $0.14 \pm 0.08^{e}$ & $0.14 \pm 0.10^{e}$ & $0.29 \pm 0.16$ & $0.62 \pm 0.50$ & $0.83 \pm 0.45$ & $1.11 \pm 0.39$ & $0.64 \pm 0.17$ \\
\hline
\end{tabular}

a Mean \pm S.D.

b Significant differences between groups and control at ${ }^{c} p<0.05$, 
less notably in patients with other intrahepatic cholestasis, the triacyclglycerol concentration in total plasma was markedly elevated, whereas that of cholesterol was within the normal range. This corresponded to an elevation of VLDL of normal composition and the presence of $\mathrm{LDL}$ enriched with respect to triacyclglycerols. In these two groups, the HDL-cholesterol concentration was significantly lower than in controls. The patients with primary biliary cirrhosis in stage III showed no apparent change in the lipoprotein triacylglycerol content, but showed major alterations in cholesterol metabolism, as indicated by the increase in cholesterol concentration in total plasma and in LDL. This increase corresponded mainly to free cholesterol. A similar situation was found in patients with acute viral hepatitis, which probably reflects the deficiency of lecithin : cholesterol acyltransferase activity characteristic of these diseases (6).

The percentages of the fatty acids ${ }^{4}$ )-myristic (C14), palmitic (C16), palmitoleic (C16:1), stearic (C18), oleic $(\mathrm{C} 18: 1)$, linoleic $(\mathrm{C} 18: 2)$, eicosatrienoic $(\mathrm{C} 20: 3 \omega 6)$, arachidonic ( $\mathrm{C} 20: 4)$ acids - in lipoprotein and total plasma triacylglycerols, cholersteryl esters and phospholipids are summarized in tables 3, 4 and 5, respectively. In each group of patients the fatty acid composition of triacylglycerols, cholesteryl esters and phospholipids was very similar for VLDL, LDL, HDL and total plasma, but there were significant differences between each group of patients and between patients and the control group. Generally, the cholesteryl ester fraction was the most sensitive, showing differences in fatty acid composition in all the patient groups with respect to controls, whereas the changes were more moderate in the phospholipids. When all the patient groups are considered together, it appears that the content of the polyunsaturated C18:2 and C20:4 is lower than in controls, a change that is compensated by moderate increases in the other fatty acids. The most important changes were observed in patients with liver cirrhosis, especially in those with uncompensated liver cirrhosis, where the linoleic acid content of total plasma cholesteryl esters was $41.6 \%$, compared with $58.3 \%$ in the controls $(\mathrm{p}<0.001)$ (tab. 4). The corresponding values for arachidonic acid were 3.2 and $4.6 \%$, respectively $(\mathrm{p}<0.05)$ (tab. 4). Among the other groups of patients, acute viral hepatitis was the most similar to the uncompensated liver cirrhosis, and therefore different from the controls. Patients with other intrahepatic cholestasis also showed significantly lower contents of linoleic acid in the three lipid fractions of lipoproteins and total plasma than the control group. The patients with primary biliary cirrhosis had a more dispersed fatty acid profile, and the

\footnotetext{
4) Fatty acids are designated by the number of carbon atoms fol-
} lowed by the number of double bonds. differences from the control group were less significant. Finally, more moderate differences were found in the subgroup of primary biliary cirrhosis I and II.

\section{Discussion}

This study documents the lipoprotein profile and the fatty acid composition of triacylglycerols, cholesteryl esters and phopsholipids from VLDL, LDL, HDL and total plasma in patients suffering from hepatic disease, with distinct types of intrahepatic cholestasis, as compared with control subjects. The main observation of the present study is that in patients with hepatobiliary disease, despite the profound changes in the lipoprotein profile and the lower abundance of polyunsaturated fatty acids in complex lipids, the fatty acid composition of all triacylglycerols, cholesteryl esters and phospholipids was very similar among the different lipoproteins and in control subjects. This indicates that in the controls, as well as in the studied patients, the cholesteryl ester transfer protein-promoted exchange of lipids between plasmatic lipoproteins is very rapid, resulting in an homogeneous distribution of lipid species between lipoprotein particles.

Apart from the liver, other tissues also synthesize cholesteryl ester transfer protein mRNA and secrete active protein $(21,22)$, so that plasma cholesteryl ester transfer protein may be derived from more than one source. In this context, it is worth mentioning that in chronic hepatitis, there is a marked decrease in plasma lecithin : cholesterol acyl transferase activity, an enzyme of exclusive hepatic origin, whereas plasma cholesteryl ester transfer protein activity and mass remain stable (6), which indicates that liver damage is not necessarily accompanied by changes in plasma lipid transfer activity. Therefore, it is very likely that the cirrhotic patients studied in this work had a normal cholesteryl ester transfer protein activity, so that the velocity of the interchange of neutral lipids between the different classes of lipoproteins was unaffected.

We consider next the difference in fatty acid composition between the complex lipids in cirrhotic patients and those in normal individuals. In general, a diminution of the polyunsaturated fatty acids $\mathrm{C} 18: 2$ and $\mathrm{C} 20: 4$ was observed, which was more pronounced in the patients with uncompensated liver cirrhosis or acute viral hepatitis. Compared with the controls, the triacylglycerols of these patients contain in smaller percentage of $\mathrm{C} 18: 2$, the phopholipids are lower in $\mathrm{C} 20: 4$, while both fatty acids are decreased in the cholesteryl esters. These lower levels are compensated by a slight increase in the rest of the fatty acids. We should point out that this fatty acid profile, both in the control group and in the patients, is similar to that found by other authors in population groups in our geographical area $(16,17,23)$. The com- 
position of fatty acids in cirrhotic patients resembles that found in situations of linoleic acid deficiency (24-27). It is known that patients with hepatobiliary disease suffer frequently from an anorexic, emetic and nauseous state, which in chronic situation can lead to severe malnutrition (28). In fact, the anthropometric estimation (29) of the two cirrhotic subgroups (data not shown) indicated that $50 \%$ of the uncompensated were clearly undernourished, while the rest were poorly nourished. Also, these data agree with the lower percentage of linoleic acid in triacylglycerols, which is used to evaluate

Tab. 3 Fatty acid composition of triacylglycerols from total plasma and lipoproteins in patients with hepatobiliary diseases and controls. the content of this fatty acid in the dietary fat (30). The compensated cirrhotic patient presumably had a better nutritional state, but this quantity fluctuated more in this subgroup, possibly reflecting a greater alimentary heterogeneity and subjacent liver damage, in spite of the fact that this clinical state is more benign.

In patients with intrahepatic cholestasis, acute viral hepatitis and other intrahepatic cholestasis, we observed that the relative content of linoleic acid was decreased in parallel with the degree of cholestasis and the severity of the hepatic disease. In the subgroups primary biliary

Plasma samples were subjected to sequential ultracentrifugation for lipoprotein isolation. The lipids were extracted and separated by TLC and the fatty acid composition was evaluated as methyl esters by GLC.

\begin{tabular}{llllllll}
\hline $\begin{array}{l}\text { Uncompen- } \\
\text { sated liver } \\
\text { cirrhosis }\end{array}$ & $\begin{array}{l}\text { Compen- } \\
\text { sated liver } \\
\text { cirrhosis }\end{array}$ & $\begin{array}{l}\text { Primary } \\
\text { biliary } \\
\text { cirrhosis in } \\
\text { stages I, II } \\
(n=8)\end{array}$ & $\begin{array}{l}\text { Primary } \\
\text { biliary } \\
\text { cirrhosis in } \\
\text { stage III } \\
(n=6)\end{array}$ & $\begin{array}{l}\text { Acute } \\
\text { viral } \\
\text { hepatitis }\end{array}$ & $\begin{array}{l}\text { Other } \\
\text { intrahepatic } \\
\text { cholestasis }\end{array}$ \\
$(n=7)$ & $(n=5)$ & $(n=5)$ & $(n=5)$ & $(n=6)$ \\
\hline
\end{tabular}

Myristic acid $\mathrm{Cl} 4: 0(\%)^{\mathrm{a}}$

$\begin{array}{ll}\text { VLDL } & 1.3 \pm 0.2 \\ \text { LDL } & 1.3 \pm 0.2 \\ \text { HDL } & 2.3 \pm 1.8 \\ \text { Total plasma } & 1.8 \pm 0.7\end{array}$

$\begin{array}{lll}2.4 \pm 1.0^{d} & 1.7 \pm 0.4^{\mathrm{c}} & 1.8 \pm 0.9 \\ 1.1 \pm 0.2 & 1.3 \pm 0.5 & 1.9 \pm 1.1 \\ 1.6 \pm 0.4 & 1.4 \pm 0.6 & 2.2 \pm 1.6 \\ 1.6 \pm 0.1 & 1.2 \pm 0.4 & 2.0 \pm 0.9\end{array}$

$2.1 \pm 1.6$
$2.6 \pm 2.4$
$2.3 \pm 1.1$
$2.4 \pm 1.3$

$1.9 \pm 0.7^{\circ}$

$1.3 \pm 0.6$

$1.3 \pm 0.7$

$1.8 \pm 0.4$

$1.1 \pm 0.2$

$0.8 \pm 0.2$

$1.0 \pm 0.4$

$1.2 \pm 0.4$

Palmitic acid $\mathrm{C} 16: 0(\%)^{\mathrm{a}}$

$\begin{array}{ll}\text { VLDL } & 28.4 \pm 3.8 \\ \text { LDL } & 25.5 \pm 3.9 \\ \text { HDL } & 25.7 \pm 5.5\end{array}$

$26.2 \pm 2.0$

$26.3 \pm 4.5$

$25.4 \pm 4.9$

$24.8 \pm 3.1$

$25.0 \pm 1.7$

Total plasma

$27.3 \pm 4.6$

$25.8 \pm 2.2$

$24.9 \pm 4.7$

$26.9 \pm 6.8$ $25.0 \pm 3.3$

$25.1 \pm 4.5$

$27.1 \pm 3.5^{c}$

$28.1 \pm 4.6^{c}$

$26.9 \pm 3.2$

$27.2 \pm 3.3$

$24.1 \pm 4.3$

$24.2 \pm 5.4$

$22.9 \pm 2.6$

$26.3 \pm 4.5$

$27.5 \pm 3.8$

$26.8 \pm 4.5$

$21.9 \pm 2.3$

$22.8 \pm 2.0$

$23.7 \pm 2.4$

Palmitoleic acid $\mathrm{C} 16: 1(\%)^{\mathrm{a}}$

$\begin{array}{ll}\text { VLDL } & 4.1 \pm 0.9 \\ \text { LDL } & 4.8 \pm 1.2 \\ \text { HDL } & 5.2 \pm 2.0 \\ \text { Total plasma } & 5.1 \pm 1.7\end{array}$

$4.0 \pm 1.2$

$4.0 \pm 1.6$

$4.5 \pm 1.5$

$4.7 \pm 1.0$

$4.6 \pm 1.4$

$3.9 \pm 1.4$

$4.7 \pm 1.9$

$4.6 \pm 1.8$

$4.2 \pm 1.4$
$4.6 \pm 3.7$
$3.7 \pm 1.9$
$5.1 \pm 3.0$

$5.2+3.0$

$6.0 \pm 1.8^{c}$

$4.8 \pm 2.7$

$4.8 \pm 2.0$

$5.0 \pm 2.4$

$4.0 \pm 1.8$

$4.9 \pm 2.8$

$4.6 \pm 3.0$

$4.0 \pm 0.4$

$3.5 \pm 0.4$

$4.0 \pm 0.4$

$4.3 \pm 0.2$

Stearic acid C18:0 (\%)

$\begin{array}{ll}\text { VLDL } & 6.6 \pm 0.7^{\mathrm{e}} \\ \text { LDL } & 5.8 \pm 0.9^{\mathrm{e}} \\ \text { HDL } & 6.2 \pm 0.5^{\mathrm{c}} \\ \text { Total plasma } & 5.3 \pm 0.9^{\mathrm{e}}\end{array}$

$5.8 \pm 1.2^{\mathrm{c}}$

$4.5 \pm 1.8$

$6.4 \pm 2.8$

$4.3 \pm 1.6$

$\begin{array}{ll}4.0 \pm 1.1 & 3.7 \pm 1.4 \\ 4.9 \pm 0.7^{c} & 4.2 \pm 1.3 \\ 4.6 \pm 1.3 & 7.6 \pm 0.5 \\ 4.7 \pm 1.0^{c} & 3.7 \pm 0.8^{c}\end{array}$

$5.4 \pm 2.3^{\circ}$

$3.0 \pm 0.8$

$6.2 \pm 2.5$

$6.1 \pm 0.8^{c}$

$5.5 \pm 1.9$

$3.7 \pm 0.5$

$4.6 \pm 1.0$

$3.8 \pm 0.9$

$3.0 \pm 0.8$

$3.6 \pm 0.3$

$4.3 \pm 1.0$

$2.7 \pm 0.2$

Oleic acid C18 : $1(\%)^{2}$

$\begin{array}{ll}\text { VLDL } & 47.3 \pm 2.5 \\ \text { LDL } & 50.8 \pm 4.7 \\ \text { HDL } & 46.0 \pm 6.7 \\ \text { Total plasma } & 50.2 \pm 3.8\end{array}$

$45.2 \pm 4.1$

$40.8 \pm 4.3$

$41.2 \pm 7.9$

$42.3 \pm 4.1$

$50.2 \pm 4.9$

$48.5 \pm 6.6$

$43.0 \pm 4.8$

$43.2 \pm 3.5$

$39.8 \pm 7.3$

$35.4 \pm 4.2^{\circ}$

$42.3 \pm 4.1$

$40.8 \pm 8.9$

$49.3 \pm 3.4$

$42.9 \pm 6.0$

$40.0 \pm 5.8$

$40.2 \pm 7.5$

$44.6 \pm 6.1$

$48.6 \pm 6.5$

$47.2 \pm 7.1$

$46.7 \pm 4^{c}$

$44.1 \pm 3.3$

$44.6 \pm 3.6$

$43.2 \pm 4.1$

$43.2 \pm 1.8$

Linoleic acid $\mathrm{C} 18: 2(\%)^{\mathrm{a}}$

$\begin{array}{lr}\text { VLDL } & 10.9 \pm 2.5^{\mathrm{e}} \\ \text { LDL } & 10.4 \pm 2.6^{\mathrm{e}} \\ \text { HDL } & 11.6 \pm 5.5^{\mathrm{e}} \\ \text { Total plasma } & 9.6 \pm 3.0^{\mathrm{e}}\end{array}$

$\begin{array}{ll}15.6 \pm 12.6 & 21.8 \pm 7.2 \\ 14.4 \pm 7.13 & 20.4 \pm 7.3 \\ 12.4 \pm 4.6^{d} & 20.2 \pm 6.8 \\ 13.0 \pm 3.0^{d} & 19.1 \pm 7.7\end{array}$

$22.0 \pm 9.4$

$22.4 \pm 8.9$

$18.05 \pm 5.4^{c}$

$14.3 \pm 6.2$

$23.8 \pm 8.8$

$17.5 \pm 3.7^{c}$

$17.5 \pm 5.7$

$16.9 \pm 5.9$

$25.7 \pm 3.4$

$21.0 \pm 10.5$

$17.7 \pm 5.6$

$17.9 \pm 6.8$

$24.5 \pm 5.5$

$23.4 \pm 4.8$

$24.2 \pm 3.6$

Arachidonic acid $\mathrm{C} 20: 4(\%)^{\mathrm{a}}$

\begin{tabular}{llllllll} 
VLDL & $1.3 \pm 1.3$ & $1.4 \pm 1.1$ & $0.6 \pm 0.5$ & $1.1 \pm 0.5$ & $1.3 \pm 0.9$ & $0.77 \pm 0.2$ & $1.0 \pm 0.5$ \\
LDL & $1.4 \pm 0.9$ & $0.9 \pm 0.3$ & $0.9 \pm 1.1$ & $1.3 \pm 1.1$ & $1.2 \pm 1.1$ & $1.2 \pm 0.5$ & $1.3 \pm 0.5$ \\
$\mathrm{HDL}$ & $2.2 \pm 1.8$ & $1.4 \pm 1.3$ & $0.8 \pm 0.7$ & $1.7 \pm 1.8$ & $1.2 \pm 0.7$ & $1.2 \pm 1.0$ & $1.0 \pm 0.5$ \\
Total plasma & $1.5 \pm 0.4$ & $1.3 \pm 0.4$ & $0.5 \pm 0.3$ & $1.3 \pm 1.0$ & $1.1 \pm 0.8$ & $0.5 \pm 0.2$ & $0.7 \pm 0.2$ \\
\hline
\end{tabular}

a Values are means $\pm S$. D. Significance differences between groups and control at ${ }^{c} p<0.05$,

${ }^{d} \mathrm{p}<0.01,{ }^{\mathrm{e}} \mathrm{p}<0.001$. 
cirrhosis II and primary biliary cirrhosis in stage III, however, the percentage of linoleic acid was maintained within the control group range, although with rather high interindividual dispersion. The fact that these patients with primary biliary cirrhosis did not lose appetite even in severe jaundice, (31) together with the diet in polyunsaturated fats they were recommended to take for their chronic hypercholesterolaemia (32), probably contribute to the unaltered content of linoleic acid observed in primary biliary cirrhosis in stages I and II and primary biliary cirrhosis in stage III patients.
The primary role of the liver in the synthesis of arachidonic acid is reinforced in the present study, which clearly documents the low content of this fatty acid in patients with hepatocellular damage. Interestingly, these data contrast with the increase of arachidonic acid in cystic fibrosis without liver affectation (29), probably as a compensating effect of the diminution of its metabolic precursor - linoleic acid - which is characteristic of this disease (33).

The changes observed in the lipoproteins deserve some comment. Patients with severe cholestasis, acute viral
Tab. 4 Fatty acid composition of cholesteryl esters from total plasma and lipoproteins in patients with hepatobiliary diseases and controls.
Plasma samples were subjected to ultracentrifugation for lipoprotein isolation. The lipids were extracted and separated by TLC and the fatty acid composition was evaluated as methyl esters by GLC.

\begin{tabular}{|c|c|c|c|c|c|c|}
\hline $\begin{array}{l}\text { Uncompen- } \\
\text { sated liver } \\
\text { cirrhosis } \\
(n=7)\end{array}$ & $\begin{array}{l}\text { Compen- } \\
\text { sated liver } \\
\text { cirrhosis } \\
(n=5)\end{array}$ & $\begin{array}{l}\text { Primary } \\
\text { biliary } \\
\text { cirrhosis in } \\
\text { stages I, II } \\
(n=8)\end{array}$ & $\begin{array}{l}\text { Primary } \\
\text { biliary } \\
\text { cirrhosis in } \\
\text { stage III } \\
(n=6)\end{array}$ & $\begin{array}{l}\text { Acute } \\
\text { viral } \\
\text { hepatitis } \\
(n=5)\end{array}$ & $\begin{array}{l}\text { Other } \\
\text { intrahepatic } \\
\text { cholestasis } \\
(n=5)\end{array}$ & $(n=6)$ \\
\hline
\end{tabular}

Myristic acid C14 : $0(\%)^{\mathrm{a}}$

$\begin{array}{llll}\text { VLDL } & 1.5 \pm 0.1 & 0.7 \pm 0.2 & 0.5 \pm 0.4 \\ \text { LDL } & 1.0 \pm 0.1 & 0.7 \pm 0.5 & 0.5 \pm 0.1 \\ \text { HDL } & 1.3 \pm 0.7 & 0.5 \pm 0.3 & 0.5 \pm 0.3 \\ \text { Total plasma } & 0.9 \pm 0.3^{\mathrm{c}} & 1.0 \pm 0.3^{\mathrm{c}} & 0.5 \pm 0.3\end{array}$

$0.5 \pm 0.2$
$0.5 \pm 0.1$
$0.7 \pm 0.3$
$0.6 \pm 0.2$

$2.0 \pm 1.5$

$1.0 \pm 0.7$

$2.6 \pm 1.2^{\mathrm{c}}$

$1.8 \pm 0.5^{\mathrm{c}}$

$13.7 \pm 3.0$

$15.6 \pm 5.0$

$15.8 \pm 5.3$

$14.4 \pm 3.6$

$15.0 \pm 2.0$

Total plasma

$15.0 \pm 0.9^{d}$

Palmitoleic acid $\mathrm{Cl} 6: 1(\%)^{\mathrm{a}}$

$\begin{array}{ll}\text { VLDL } & 5.0 \pm 0.9 \\ \text { LDL } & 5.7 \pm 1.6^{\mathrm{c}} \\ \text { HDL } & 6.5 \pm 2.2^{\mathrm{d}} \\ \text { Total plasma } & 5.3 \pm 0.9\end{array}$

$12.4 \pm 1.8^{\mathrm{c}}$

$12.5 \pm 1.5$

$12.1 \pm 1.6$

$12.7 \pm 2.6$

$3.6 \pm 3.7$

$3.5 \pm 2.5$

$3.7 \pm 4.6$

$4.1 \pm 3.8$
$0.9 \pm 0.5$

$0.8 \pm 0.3$

$1.0 \pm 0.2$

$0.9 \pm 0.3$

$3.2 \pm 1.5^{\mathrm{d}}$

$2.2 \pm 0.9^{c}$

Oleic acid $\mathrm{C} 18: 1$ (\%)

$\begin{array}{ll}\text { VLDL } & 33.6 \pm 4.7^{\mathrm{c}} \\ \text { LDL } & 33.2 \pm 6.8^{\mathrm{d}} \\ \text { HDL } & 33.2 \pm 4.4^{\mathrm{d}} \\ \text { Total plasma } & 32.1 \pm 5.1^{\mathrm{d}}\end{array}$

$27.2 \pm 6.0$

$26.3 \pm 7.5$

$26.2 \pm 7.7$

$25.9 \pm 5.0$

Linoleic acid C18 : $2(\%)^{\mathrm{a}}$

$\begin{array}{ll}\text { VLDL } & 39.9 \pm 8.3^{\mathrm{c}} \\ \text { LDL } & 41.5 \pm 8.1^{\mathrm{d}} \\ \text { HDL } & 37.0 \pm 7.2^{\mathrm{e}} \\ \text { Total plasma } & 41.6 \pm 4.2^{\mathrm{e}}\end{array}$

$52.3 \pm 9.0$

$46.4 \pm 12.7$

$45.7 \pm 13.5$

$49.1 \pm 11.4$

$\begin{array}{ll}56.9 \pm 12.2 & 48.9 \pm 7.9 \\ 55.5 \pm 9.9 & 54.7 \pm 9.2 \\ 55.1 \pm 11.0 & 58.6 \pm 6.4 \\ 56.9 \pm 13.2 & 53.2 \pm 8.7\end{array}$

$23.7 \pm 7.7$

$21.1 \pm 4.9$

$21.0 \pm 5.7$

$21.5 \pm 5.8$
$17.2 \pm 4.3^{\mathrm{c}}$

$13.9 \pm 1.2^{\mathrm{c}}$

$16.6 \pm 4.4^{\mathrm{c}}$

$15.8 \pm 1.6^{\mathrm{c}}$

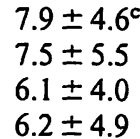

$0.8 \pm 0.3$
$0.8 \pm 0.5$
$1.1 \pm 0.2$
$0.9 \pm 0.4$

$20.5 \pm 4.0$

$19.8 \pm 5.4$

$15.3 \pm 2.9$

$20.5 \pm 5.0$

$23.8 \pm 6.5$
$22.7 \pm 5.5$
$24.0 \pm 4.3$
$23.8 \pm 5.6$

$36.1 \pm 8.2^{2}$

$42.7 \pm 6.8^{\circ}$

$37.6 \pm 11.3^{c}$

$42.2 \pm 3.9^{\mathrm{d}}$
$1.4 \pm 1.7$
$0.9 \pm 0.4$
$0.8 \pm 0.3$
$0.8 \pm 0.3^{c}$

$0.7 \pm 0.4$

$0.7 \pm 0.5$

$0.5 \pm 0.1$

$0.5 \pm 0.1$

$14.6 \pm 3.2^{c}$

$14.3 \pm 2.5$

$12.7 \pm 1.9$

$14.5 \pm 2.0$

$6.2 \pm 4.0$

$4.7 \pm 3.7$

$3.9 \pm 4.1$

$6.1 \pm 4.3$

$10.1 \pm 0.5$

$11.2 \pm 1.0$

$10.7 \pm 0.6$

$11.7 \pm 0.6$

$3.2 \pm 1.6$

$2.8 \pm 1.0$

$2.5 \pm 0.5$

$2.5 \pm 0.4$

$2.4 \pm 1.5$

$1.7 \pm 1.0$

$2.1 \pm 1.0$

$1.2 \pm 0.3$

$1.7 \pm 0.9$

$1.5 \pm 1.6$

$1.0 \pm 0.2$

$0.9 \pm 0.2$

$26.7 \pm 4.4$

$27.8 \pm 4.7^{\mathrm{d}}$

$25.7 \pm 3.5^{\mathrm{c}}$

$26.6 \pm 3.1^{c}$

$22.5 \pm 4.5$

$18.8 \pm 2.8$

$18.4 \pm 3.2$

$20.7 \pm 2$

$42.3 \pm 7.2^{\mathrm{c}}$

$44.2 \pm 7.8^{\mathrm{c}}$

$46.5 \pm 6.7^{\mathrm{c}}$

$45.6 \pm 7.8^{c}$

$3.9 \pm 0.5^{\mathrm{c}}$
$5.2 \pm 1.0^{\mathrm{c}}$
$5.1 \pm 1.2^{\mathrm{c}}$
$3.8 \pm 0.6^{\mathrm{c}}$

$4.7 \pm 1.0$

$5.5 \pm 1.8$

$6.0 \pm 1.5$

$4.9 \pm 2.3$
$54.4 \pm 6.0$

$57.7 \pm 4.7$

$58.9 \pm 3.0$

$58.3 \pm 3.7$

Arachidonic acid C20 : $4(\%)^{\mathrm{a}}$

\begin{tabular}{llllll} 
VLDL & $3.0 \pm 1.2^{\mathrm{c}}$ & $3.8 \pm 1.0$ & $5.2 \pm 2.7$ & $5.2 \pm 2.3$ & $3.9 \pm 0.5^{\mathrm{c}}$ \\
$\mathrm{LDL}$ & $3.6 \pm 1.3^{\mathrm{d}}$ & $4.7 \pm 1.4^{\mathrm{c}}$ & $5.7 \pm 2.0$ & $6.2 \pm 2.1$ & $5.2 \pm 1.0^{\mathrm{c}}$ \\
$\mathrm{HDL}$ & $4.1 \pm 1.7^{\mathrm{e}}$ & $4.3 \pm 1.4^{\mathrm{d}}$ & $6.3 \pm 2.4$ & $6.3 \pm 1.6$ & $5.1 \pm 1.2^{\mathrm{c}}$ \\
Total plasma & $3.2 \pm 1.5^{\mathrm{c}}$ & $4.0 \pm 1.0^{\mathrm{c}}$ & $5.3 \pm 1.2$ & $5.7 \pm 1.7$ & $3.8 \pm 0.6^{\mathrm{c}}$ \\
\hline
\end{tabular}

\footnotetext{
a Values are means \pm S.D. Significance differences between groups and control at ${ }^{c} p<0.05$,
${ }^{d}<<0.01,{ }^{c} p<0.001$.
} 
hepatitis and primary biliary cirrhosis III, showed increased concentrations of free cholesterol, which were probably related to the well-known decreased activity of lecithin : cholesterol acyltransferase in this pathologic state $(5-7)$. In the acute viral hepatitis group, increased levels of triacylglycerols were observed in agreement with previous results (34). In contrast, patients with liver

Tab. 5 Fatty acid composition of phospholipids from total plasma and lipoproteins in patients with hepatobiliary diseases and controls.

Plasma samples were subjected to sequential ultracentrifugation for cirrhosis had decreased plasma levels of triacylglycerols, mainly due to a marked decrease in the number of VLDL particles. We found in previous work that VLDL from cirrhotic patients had an altered apolipoprotein composition, with a very low content of apolipoprotein E (34-36), which probably indicates a reduced production of VLDL by the liver in this disease. In addition,

lipoprotein isolation. The lipids were extracted and separated by TLC and the fatty acid composition was evaluated as methyl esters by GLC.

$\begin{array}{lllllll}\text { Uncompen- } & \text { Compen- } & \text { Primary } & \text { Primary } & \text { Acute } & \text { Other } & \text { Controls } \\ \text { sated liver } & \text { sated liver } & \text { biliary } & \text { biliary } & \text { viral } & \text { intrahepatic } & \\ \text { cirrhosis } & \text { cirrhosis } & \text { cirrhosis in } & \text { cirrhosis in } & \text { hepatitis } & \text { cholestasis } & \end{array}$

$\begin{array}{llllll}(n=7) & (n=5) & \begin{array}{l}\text { stages } 1,11 \\ (n=8)\end{array} & \begin{array}{l}\text { stage }(n=6) \\ (n=5)\end{array} & (n=5)\end{array} \quad(n=6)$

Myristic acid C14 : $0(\%)^{\mathrm{a}}$

$\begin{array}{llllllll}\text { VLDL } & 0.4 \pm 0.2 & 0.3 \pm 0.1 & 0.4 \pm 0.1 & 0.6 \pm 0.3 & 1.1 \pm 0.9 & 0.3 \pm 0.1 & 0.5 \pm 0.2 \\ \text { LDL } & 0.8 \pm 0.4 & 0.5 \pm 0.1 & 0.4 \pm 0.1 & 0.4 \pm 0.1 & 0.5 \pm 0.3 & 0.4 \pm 0.3 & 0.4 \pm 0.1 \\ \text { HDL } & 1.1 \pm 0.8 & 0.3 \pm 0.1 & 0.4 \pm 0.1 & 0.5 \pm 0.3 & 0.5 \pm 0.2 & 0.9 \pm 0.5^{\mathrm{c}} & 0.3 \pm 0.1 \\ \text { Total plasma } & 0.7 \pm 0.3^{c} & 0.5 \pm 0.1 & 0.3 \pm 0.1 & 0.7 \pm 0.4 & 0.5 \pm 0.3 & 0.4 \pm 0.2 & 0.3 \pm 0.1\end{array}$

Palmitic acid C16 : 0 (\%)

$\begin{array}{lll}\text { VLDL } & 31.5 \pm 1.8 & 32.0 \pm 6.2 \\ \text { LDL } & 32.8 \pm 2.0 & 32.7 \pm 3.4 \\ \text { HDL } & 28.4 \pm 2.2 & 32.6 \pm 6.8\end{array}$

Total plasma $\quad 31.1 \pm 1.9 \quad 32.9 \pm 3.6$

Palmitoleic acid C16:1 (\%)

$\begin{array}{ll}\text { VLDL } & 1.4 \pm 0.6 \\ \text { LDL } & 1.8 \pm 0.8^{c} \\ \text { HDL } & 1.8 \pm 0.6 \\ \text { Total plasma } & 1.5 \pm 0.6^{c}\end{array}$

Stearic acid C18 : $0(\%)^{\mathrm{a}}$

VLDL

LDL

$16.3 \pm 0.4$

$14.0 \pm 3.1$

HDL

$14.1 \pm 3.2$

Total plasma

$15.3 \pm 0.8$

$1.9 \pm 0.4^{\mathrm{c}}$

$1.3 \pm 0.9$

$1.5 \pm 0.7^{c}$

$1.8 \pm 0.2^{\mathrm{d}}$

$30.8 \pm 3.9$

$34.6 \pm 4.1$

$32.3 \pm 3.8$

$33.1 \pm 3.4$

$30.1 \pm 3.3$

$35.6 \pm 4.8$

$31.4 \pm 4.9$

$32.5 \pm 4.4$

$31.2 \pm 2.0$

$33.1 \pm 2.6$

$30.3 \pm 1.4$

$31.8 \pm 2.0$

$1.2 \pm 0.5$
$0.7 \pm 0.6$
$1.0 \pm 0.8$
$0.6 \pm 0.5$

$1.3 \pm 1.1$

$1.1 \pm 0.8$

$1.9 \pm 1.2$

$1.0 \pm 0.7$

$1.9 \pm 1.4$

$0.9 \pm 0.4$

$1.2 \pm 0.5^{\mathrm{c}}$

$1.3 \pm 0.5$

$14.0 \pm 3.6$

$13.7 \pm 3.4$

$12.8 \pm 5.0$

$14.0 \pm 2.8$

$16.7 \pm 2.8$

$16.1 \pm 2.5$

$15.9 \pm 1.7$

$16.9 \pm 2.6$

$16.8 \pm 2.0$

$16.3 \pm 5.4$

$15.7 \pm 2.5$

$15.2+2.9$

$17.2 \pm 0.9^{c}$

$16.5 \pm 0.7$

$16.8 \pm 1.2$

$16.0 \pm 0.4$

$14.2 \pm 4.4$

$13.0 \pm 5.3$

$12.0 \pm 4.1$

$21.6 \pm 8.6$

$20.9 \pm 6.1$

HDI

$20.2 \pm 3.8^{\mathrm{d}}$

$21.9 \pm 2.7^{e}$

$20.7 \pm 4.4$

$13.9 \pm 2.2$

$12.8+3.0$

$12.9 \pm 2.1$

$12.2 \pm 3.3$

$17.2 \pm 3.0^{\circ}$

$15.2 \pm 3.9$

$15.8 \pm 3.1^{\mathrm{c}}$

$16.1 \pm 3.4$

$\pm 4.3$

$14.5 \pm 4.3$

$14.5 \pm 2.2$

$15.4 \pm 2.4$

$25.9 \pm 7.2$

$32.1 \pm 7.8$

$26.4 \pm 6.8$

$18.8 \pm 2.0^{\circ}$

$21.5 \pm 4.6$

$20.0 \pm 2.7$

$23.1 \pm 7.2$

$24.9 \pm 5.8$

$24.6 \pm 6.5$

$21.6 \pm 5.7$

$25.9 \pm 8.3$

$25.2 \pm 5.0$

$20.6 \pm 2.1$

$21.0 \pm 2.1$

$21.7 \pm 2.4$

$20.4 \pm 3.5$

$20.1 \pm 3.8$

$\begin{array}{ll}2.2 \pm 0.9 & 2.4 \pm 1.2 \\ 2.4 \pm 0.8 & 3.1 \pm 1.3 \\ 2.5 \pm 0.6 & 3.5 \pm 1.2 \\ 2.7 \pm 1.1 & 3.2 \pm 0.9\end{array}$

$4.2 \pm 1.1$

$4.3 \pm 1.6$

$4.9 \pm 0.6$

$4.1 \pm 1.5^{\mathrm{c}}$

$1.5 \pm 0.9 \quad 2.4 \pm 1.9$

$1.5 \pm 1.1^{\mathrm{c}} \quad 2.7 \pm 1.6$

$1.9 \pm 0.5 \quad 2.4 \pm 1.6$

$\begin{array}{ll}5.1 \pm 3.4^{\mathrm{d}} & 9.6 \pm 3.6 \\ 5.5 \pm 2.1^{\mathrm{d}} & 7.9 \pm 2.3 \\ 5.9 \pm 1.5^{\mathrm{d}} & 9.9 \pm 3.3 \\ 6.6 \pm 2.6^{\mathrm{c}} & 8.7 \pm 1.9\end{array}$

$8.9 \pm 1.6^{c}$

$7.9 \pm 2.2$

$9.2 \pm 1.1^{\mathrm{c}}$

$9.0 \pm 2.1$

$9.8 \pm 2.6$

$9.0 \pm 1.4$

$10.8 \pm 1.3$

$9.3 \pm 1.9$

HDL

$7.6 \pm 2.8^{c}$

$8.7 \pm 1.9$

$9.0 \pm 2.9$

$8.9 \pm 1.9$
$30.4 \pm 3.1$

$33.8 \pm 3.4$

$30.3 \pm 1.6$

$34.3 \pm 2.5$

$0.9 \pm 0.2$

$0.7 \pm 0.3$

$0.7 \pm 0.2$

$0.8 \pm 0.2$

$16.1 \pm 0.8$

$15.6 \pm 0.7$

$16.3 \pm 0.9$

$16.5 \pm 1.2$

$12.8 \pm 1.9$

$12.8 \pm 1.9$

$11.9 \pm 1.9$

$12.9 \pm 1.9$

$24.3 \pm 2.2$

$22.8 \pm 1.8$

$22.9 \pm 1.9$

$23.0 \pm 1.5$

$3.0 \pm 1.1$

$3.1 \pm 1.5$

$3.1 \pm 0.7$

$2.3 \pm 0.6$

$12.1 \pm 2.1$

$12.5 \pm 3.1$

$8.4 \pm 2.7 \quad 10.2 \pm 1.8$

a Values are means \pm S.D. Significance differences between groups and control at ${ }^{c} p<0.05$,

${ }^{\mathrm{d}} \mathrm{p}<0.01,{ }^{\mathrm{e}} \mathrm{p}<0.001$. 
we observed that the LDL-triacylglycerol concentration is increased in these patients as compared with controls. Actually, LDL from these patients appear to be enriched with respect to triacylglycerols because of the elevated LDL triacylglycerol cholesterol mass ratio. No Lp-X was detected in the LDL fraction by agarose electrophoresis (data not shown). Whether the decreased unsaturation of fatty acids in the lipids of these lipoproteins contributes directly to the altered metabolism of LDL in these patients deserves further investigation.

In conclusion, in a broad group of patients with liver cirrhosis or other related pathologies, we demonstrated profound changes in plasma lipid levels and lipoprotein distribution, and a diminished content of linoleic acid as indicative of the undernourished state of some of these patients. Despite these alterations, triacylglycerols and cholesteryl esters were homogeneously distributed

\section{References}

1. Yang C, Manogian D, Pao Q, Lee F, Knaap RD, Gotto AM Jr, et al. Lecithin cholesterol acyl transferase. Functional regions and a structural model of the enzyme. J Biol Chem 1987; 262(7):3086-91.

2. Francone OL, Gurakar A, Fielding CJ. Distribution and functions of lecithin cholesterol acyltransferase and cholesteryl ester transfer protein in plasma lipoproteins. J Biol Chem 1989; 264:7066-72:

3. McIntyre N. Plasma lipids and lipoproteins in liver disease. Gut 1978; 19:526-30.

4. Flore $\mathrm{CH}$. Apolipoprotein $\mathrm{E}$ in hepatocellular liver disease. Scand J Clin Lab Invest 1988; 84:199-203.

5. Floren $\mathrm{CH}$, Chen $\mathrm{C}$, Franzen J, Albers JA. Lecithin cholesterol acyl transferase in liver disease. Scand J Clin Lab Invest 1987; 47:613-7.

6. Tahar D, Nakanishi T, Akazawa S, Yamaguchi Y, Yamamoto $\mathrm{H}$, Akashi $\mathrm{M}$, et al. Lecithin-cholesterol acid transferase and lipid transfer activities in liver disease. Metabolism 1993; 42(1):19-23.

7. Abbey $M$, Calvert GD. D-Galactosamine induced hepatitis in the rabbit: effect on lecithin : cholesterol acyltransferase activity, plasma lipid transfer protein activity and high density lipoproteins. Comp Biochem Physiol 1986; 85B:659-67.

8. Hiraoka H, Yamashita S, Matsuzawa Y, Masuhauru K, Shuichi $\mathrm{N}$, Naohikos S, et al. Decrease of hepatic triglyceride lipase levels and increase of cholesteryl ester transfer protein levels in patients with primary biliary cirrhosis: relationship to abnormalities in high-density lipoprotein. Hepatology 1993; 18/ 1):103-10.

9. Johson SB, Gordon E, McClain C, Low G, Holman R. Abnormal polyunsaturated fatty acid patterns of serum lipids in alcoholism and cirrhosis: arachidonic acid deficiency in cirthosis. Proc Natl Acad Sci USA 1985; 82:1815-8.

10. Lecerf J, Rossignol A, Véricel E, Thies F, Farnier M, Legarde $M$, et al. Variations in the fatty acid composition of lipid classes from lipoproteins in elderly women. Atherosclerosis 1993; 98:241-9.

11. Sassolas A, Lagardo M, Guicherdant M, Quicy C, Decha Vanne M. Plasma lipoproteins and fatty acid composition after mini-pill. Contraception 1983; 28/4):357-8.

12. Oschry Y, Esemberg S, Rat plasma lipoproteins: re-evaluation of a lipoprotein system in an animal devoid of cholesteryl ester transfer activity. J Lip Res 1982; 23:1099-205.

13. Terpstra AHM, Stucchi AF, Foxall TL, Shwaery GT, Vespa $\mathrm{DB}$, Niclosi RJ. Unidirectional transfer in vivo of high-density lipoprotein cholesteryl esters to lower-density lipoproteins in the pig, an animal species without plasma cholesteryl ester transfer activity. Metabolism 1993; 42:1524-30. among the different plasma lipoproteins in cirrhotic patients as well as in normal individuals. This indicates that the plasma cholesteryl ester transfer protein activity present in these conditions is high enough to promote a rapid exchange of these lipids between the lipoproteins and it demonstrates the possible importance of extrahepatic synthesis of cholesteryl ester transfer protein.

\section{Acknowledgements}

$\cdot 1$

We thank Dr. A. Cano of the Gastroenterology Service, Hospital Ramón y Cajal for patient care. We thank Drs. J. J. Arias and J. Calabuig from Ambulatorio San Blas and Dr. C. Grande and Dr. Olveira of the Hospital of $\mathrm{La} \mathrm{Paz}$ for helping to find $\mathrm{HAV}$ patients. We thank A. Reviriego, Carmen Coello and Maria Cruz Botas for technical assistance, and Shirley McGrath for linguistic assistance. This work was supported in part by the Fondo de Investigaciones Sanitarias (94/0484), Spain.

14. Palombo JD, Lopes SM, Zeisel SH, Jenkis RL, Albers JJ, Blackburn GL, et al. Effectiveness of orthotopic liver transplantation on the restoration of cholesterol metabolism in patients with end-stage liver disease. Gastroenterology 1987; 93:1170-7.

15. Cabré E, Periago JL, Abad-La Cruz A, Gil A, Gonzalez Huix F, Sanchez de Medina F, et al. Polyunsaturated fatty acid deficiency in liver cirrhosis, its relation to associated protein energy malnutrition. Preliminary reports. Am J Gastroenterology 1988; 83(7):712-7.

16. González J, Periago JL, Gil A, Cabré A, Abad-Cruz A, Gassull $\mathrm{MA}$, et al. Malnutrition related polyunsaturated fatty acid changes in plasma lipid fractions of cirrhotic patients. Metabolism 1992; 41(9):954-60.

17. Iglesias A, Contreras JA, Martínez-Pardo M, Entrala A, Herrera $\mathrm{E}$, Lasunción MA. Cholesteryl ester transfer activity in lipoprotein lipase deficiency and other primary hypertriglyceridemias. Clin Chim Acta 1993; 221:73-9.

18. Garland PB, RAndle PJ. A rapid enzymatic assay for glycerol. Nature (London) 1962; 196:987-8.

19. Folch J, Lees M, Sloane Stanley GH. A simple method for the isolation and purification of total lipids from animal tissues. J Biol Chem 1957; 226:497-9.

20. Jian XG, Moulan P, Quinet E, Goldberg IJ, Jacab LK, Agellan LB, et al. Mammalian adipose tissue and muscle are major sources of lipid transfer protein mRNA. J Biol Chem 1991; 266:4631-9.

21. Faust RA, Albers JJ. Regulated vectorial secretion of cholesteryl ester transfer protein (LTP-I) by $\mathrm{CaCo}-2$ model of human enterocyte epithelium. J Biol Chem 1988; 263:8786-9.

22. Arranz MI. Cromatografía gas líquido de los ácidos grasos de triglicéridos, lecitinas, ésteres de colesterol y ácidos grasos libres. Biométrica 1980; V(1):31-5.

23. Caren $R$, Corbo L. Plasma fatty acids in pancreatic cystic fibrosis and liver disease. J Clin Endocrinol 1966; 26:470-7.

24. Suarez L. Arranz MI, Camarero C, Escobar H. Cimetidine in cystic fibrosis. Effect on steatorrhoea and serum fatty acids. Acta Paediatr Belg 1980; 33:23-5

25. Bjerve KS, Mostad IL, Thorensen L. Alpha-linolenic acid deficiency in patients on long-term gastric-tube feeding: estimation of linolenic acid and long chain unsaturated n-3 fatty acid requirement in man. Am J Clin Nutr 1987; 45:66-7.

26. Asciutti-Moura L, Guilland JC, Fuchs F, Ricard D, Klepping J. Fatty acid composition of serum lipids and its relation to diet in an elderly institutionalized population. Am J Clin Nutr 1988; 48:980-7. 27. Mezey E. Liver disease and nutrition. Gastroenterology 1978;
74/4):770-3. 
28. Dugdale AE. Griffiths $M$. Estimating fat body mass from anthropometric data. Am J Clin Nutr 1979; 32:2400-3.

29. Moore RA, Oppert S, Eaton P, Mann JI. Triglyceride fatty acids confirm a change in dietary fat. Clin Endocrinol 1977; 7:143-9.

30. Chantar C, Rodés J. In: Interamericana, Mc Graw Hill, editors. Enfermedades del aparato digestivo. 1985:65-8.

31. Simpson HCR. Barker K, Carter RD, Cassels E, Mann JI. Low dietary intake of linoleic acid predisposes to myocardial infarction. Br Med J 1983; 285:683-5.

32. Roselund ML, Kim HK, Kritcheusy D. Essential fatty acids in cystic fibrosis. Nature 1974; 251:719-20.

33. Perales J, Lasunción MA, Cano A, Martin Scapa MA, Maties $M$, Herrera E. Cambios en el perfil lipídico en haptopatias crónicas. Med Clin 1994; 102:10-4.
34. Seidel D. Lipoproteins in liver disease. J Clin Chem Clin Biochem 1987; 25:541-1.

35. Janh CE, Schacfer EJ, Taam LA, Hoofnagle H, Lindgren FT, Albets $\mathrm{JJ}$, et al. Lipoprotcin abnormalitics in primary biliary cirrhosis. Gastroenterology 1985; 89:1266-8.

Received April 20/September 4, 1995/Fehruary 5, 1996

Corresponding author: Maria Isabel Arranz Peña, Servicio de Bioquímica Clínica, Hospital Ramón y Cajal, E-28034 Madrid, Spain 
